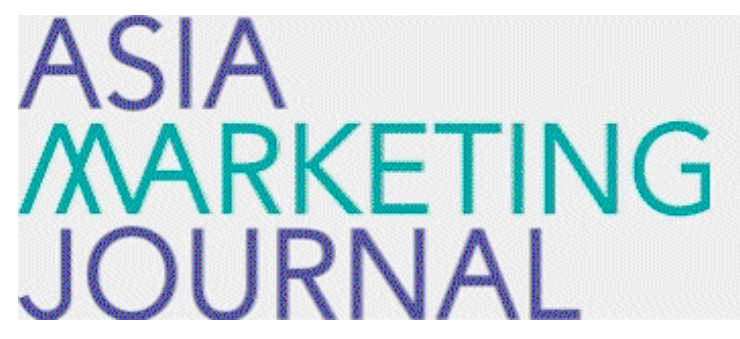

ASIA MARKETING JOURNAL

Volume 17 | Issue 2

Article 7

7-31-2015

\title{
ASIA MARKETING JOURNAL 제17권 제2호 목차
}

Follow this and additional works at: https://amj.kma.re.kr/journal

Part of the Marketing Commons

\section{Recommended Citation}

(2015) "ASIA MARKETING JOURNAL 제17권 제2호 목 차," Asia Marketing Journal: Vol. 17 : Iss. 2 , Article 7.

Available at: https://doi.org/10.53728/2765-6500.1390

This Article is brought to you for free and open access by Asia Marketing Journal. It has been accepted for inclusion in Asia Marketing Journal by an authorized editor of Asia Marketing Journal. 


\section{Vol. 17 No. 02 July 2015}

\section{$<$ Research Paper $>$}

Advertising Distinctiveness and Consumer Memory

in Competitive Ad Environments

Ryosuke Takeuchi

The Conceptualization and Development of Advertisement-Evoked

Imagination Scale

Ike Janita Dewi - Swee-Hoon Ang

Internal Service Recovery's Influence on Frontline Service Employees'

Satisfaction and Loyalty

Taeshik Gong

Counting Up while Doing Tasks Makes You Feel More

Difficult than Counting Down

Hee-Kyung Ahn

The Impact of Servicescape on Customer Experience Quality through

Employee-to-customer Interaction Quality and Peer-to-peer Interaction

Quality in Hedonic Service Settings

Beomjoon Choi · Hyun Sik Kim

Priority Factors of Service Recovery Strategy in Distribution Channel

Sang-Lin Han · Kyung Sik Jung · Myoung Soung Lee - Jong Won Lee 